Full Paper

\title{
Synthesis and study of the stability of phosphane palladacycles ${ }^{+}$
}

\author{
Paula Munín-Cruz*, Francisco Reigosa, Fátima Lucio-Martínez, Pablo Romarís, Juan M. Ortigueira, José M. \\ Vila, M. Teresa Pereira
}

Departmento de Química Inorgánica, Universidade de Santiago de Compostela, Avenida. das Ciencias s/n, 15782 Santiago de Compostela, Spain

* Correspondence: paula.munin@usc.es

+ Presented at the 22nd International Electronic Conference on Synthetic Organic Chemistry, 15 November-15 December 2018.

Received: date; Accepted: date; Published: date

\begin{abstract}
The chemistry of phosphane palladacycles[1] has been amply developed in last years. This kind of chemistry results interesting due to their applications in numerous fields such as organic synthesis[2], catalysis[3] or as potential biologically active materials[4]. Palladacycles bearing the diphosphine dppm have been described before[5] and we now report a new behavior shown by palladacycles of the type $\left[\mathrm{Pd}_{2}\left(\mathrm{Ph}_{2} \mathrm{PCH}_{2} \mathrm{PPh}_{2}-\mathrm{P}, \mathrm{P}\right)_{2}(\mathrm{C}, \mathrm{N}: \mathrm{C}, \mathrm{N})\right]$.

In this case the coordination of $d p p m$ spontaneously shifts from chelate to bridging mode in solution giving a core A-frame conformation with two palladium atoms with a chlorido or bromido ligand between them.
\end{abstract}

Keywords: Palladacycles, Cyclometallated compounds, dppm

\section{Introduction}

Palladium cyclometallated compounds and their derivatives have been widely studied in past years. There are many studies related to cyclometallated compounds derived from a wide variety of ligands and metals. In this work, a Schiff base was used as ligand for metallation; specifically the tetradentate $[(\mathrm{C}, \mathrm{N}: \mathrm{C}, \mathrm{N})]$ ligand derived from the condensation between 2,3,4-trimethoxybenzaldehyde and 4,4'-oxydianiline were chosen.

Diphosphines such as $\mathrm{Ph}_{2} \mathrm{PCH}_{2} \mathrm{PPh}_{2}$ (dppm) present different coordination modes towads metal centers. It usually acts as chelate due to the thermodynamic stability related to coordination rings but nevertheless it may also appear bridging two metal centers. This behavior depends on the relative stability between both conformations.

In this work we report a gradual shift from a chelating to a bridging mode of this diphosphine when the metal center is palladium. 


\section{Materials and methods}

2.1. Synthesis of the ligand
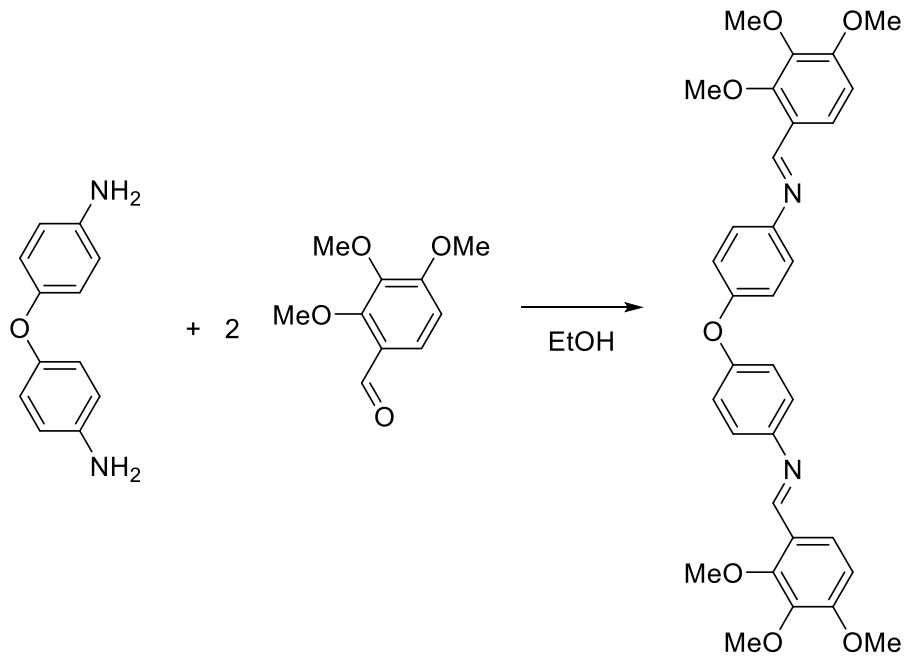

Scheme 1. Synthesis reaction of the ligand

In a round bottom flask a 1:2 mixture of $\left(\mathrm{p}-\mathrm{NH}_{2} \mathrm{C}_{6} \mathrm{H}_{4}\right)_{2} \mathrm{O}$ and $2,3,4-(\mathrm{MeO})_{3} \mathrm{C}_{6} \mathrm{H}_{2} \mathrm{CHO}$ in ethanol $\left(50 \mathrm{~cm}^{3}\right)$ was stirred at room temperature during $24 \mathrm{~h}$. A white precipitate was formed, which was filtered off, washed with water and dried under vacuum.

\subsection{Synthesis of the cyclometallated compound}
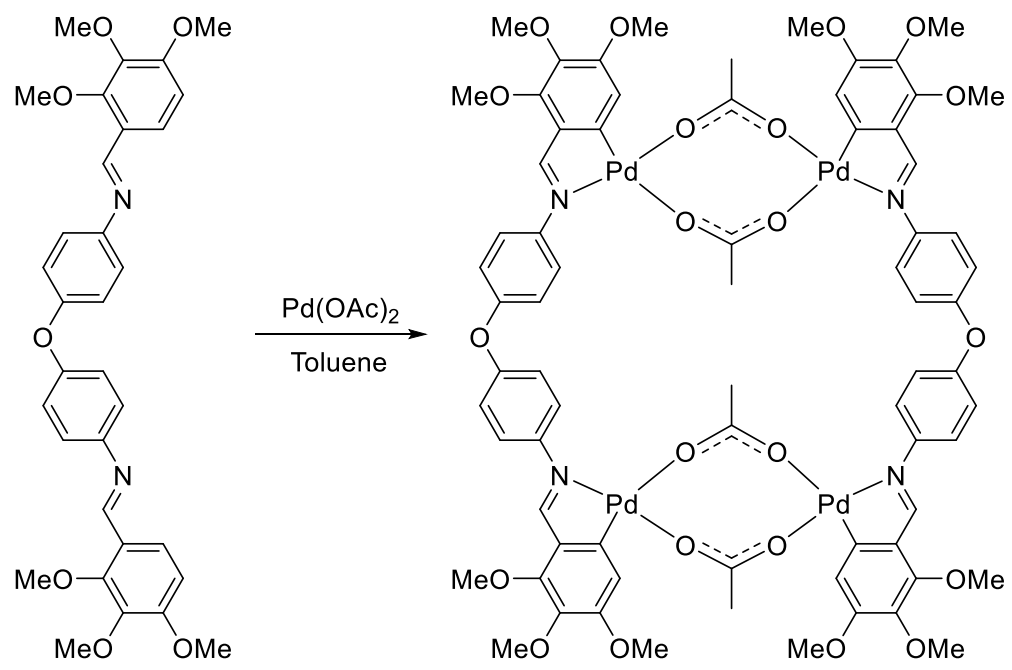

Scheme 2. Synthesis reaction of the cyclometallated compound

In a round bottom flask the ligand $(0.500 \mathrm{~g})$ was dissolved in toluene $\left(30 \mathrm{~cm}^{3}\right)$. Then, palladium(II) acetate (2 eq.) was added and the resulting mixture was stirred at $55^{\circ} \mathrm{C}$ for $24 \mathrm{~h}$. After cooling to r. t. the red oil formed was separated, to afford the final product as a red solid. 

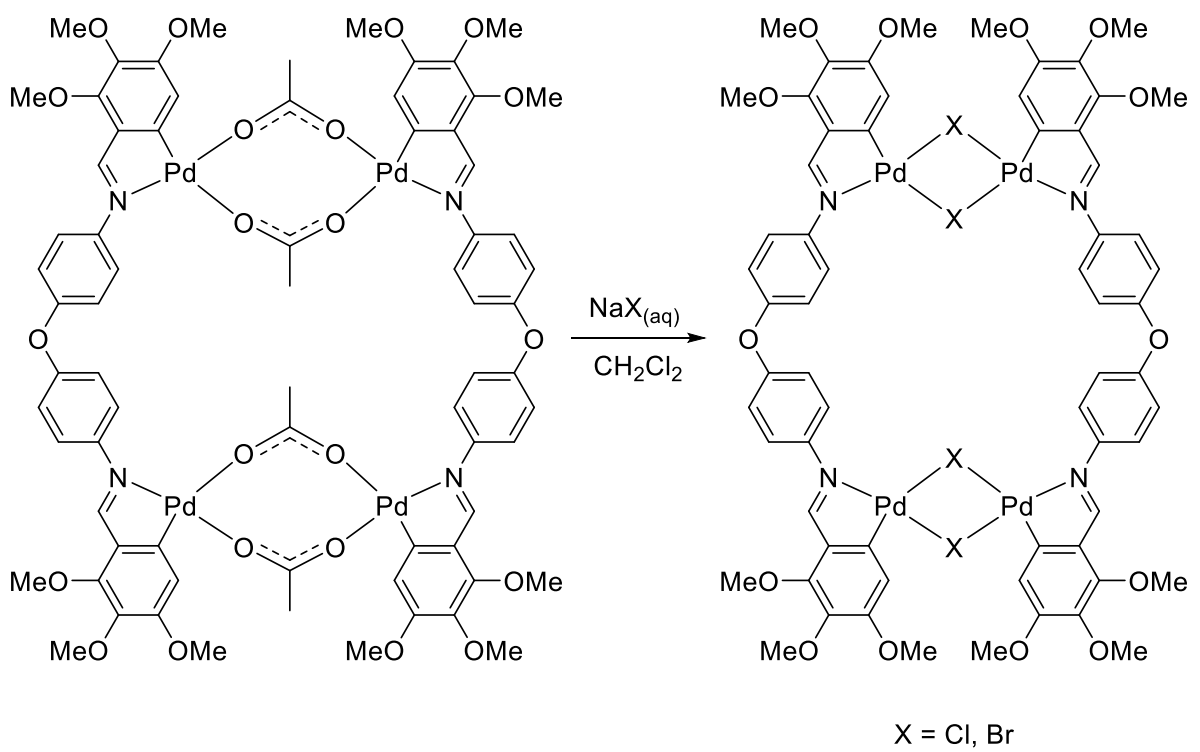

Scheme 3. Synthesis reaction of the halide derivatives

In a round bottom flask a solution of the cyclometallated precursor $(0.450 \mathrm{~g})$ in $25 \mathrm{~cm}^{3}$ of dichloromethane was treated with $35 \mathrm{~cm}^{3}$ of an aqueous solution of $\mathrm{NaX}(0.05 \mathrm{M})$ and the mixture was stirred at room temperature. After eight hours the organic layer was isolated and the solvent was removed under reduced pressure. Later, the residue was recrystallized ofrom a mixture of dichloromethane-hexane to give a yellow solid.

\subsection{Synthesis of the phosphane palladacycles}
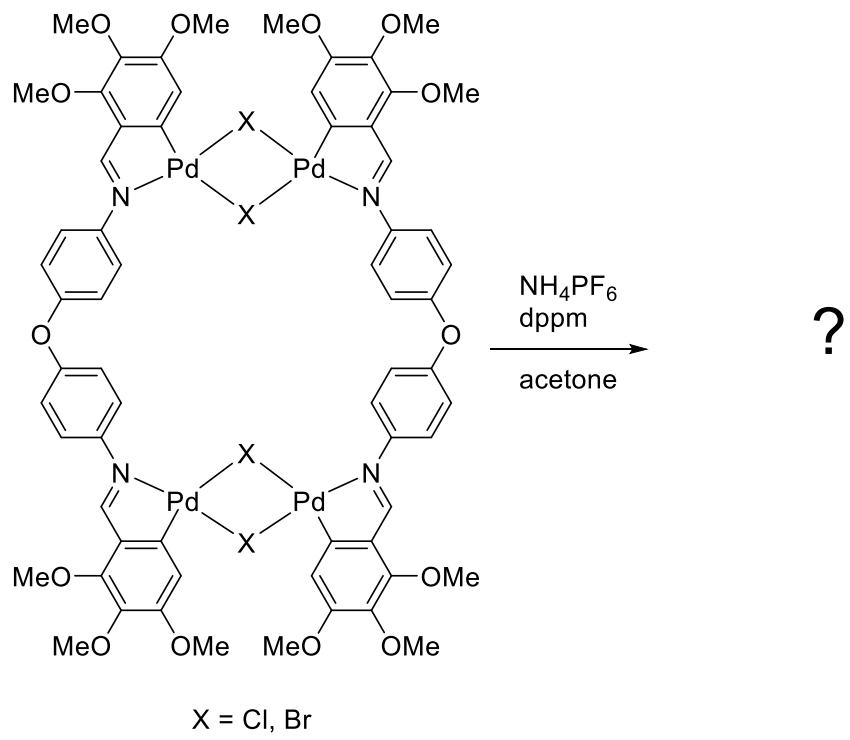

Scheme 4. Synthesis reaction of the final products

$\mathrm{Ph}_{2} \mathrm{PCH}_{2} \mathrm{PPh}_{2}(0.020 \mathrm{mmol})$ and ammonium hexafluorophosphate $(0.024 \mathrm{mmol})$ were added to a solution of the cyclometallated compound $(8.5 \mathrm{mg}, 0.005 \mathrm{mmol})$ in acetone- $\mathrm{d}_{6}\left(0.6 \mathrm{~cm}^{3}\right)$ and left to stand until complete conversion. 


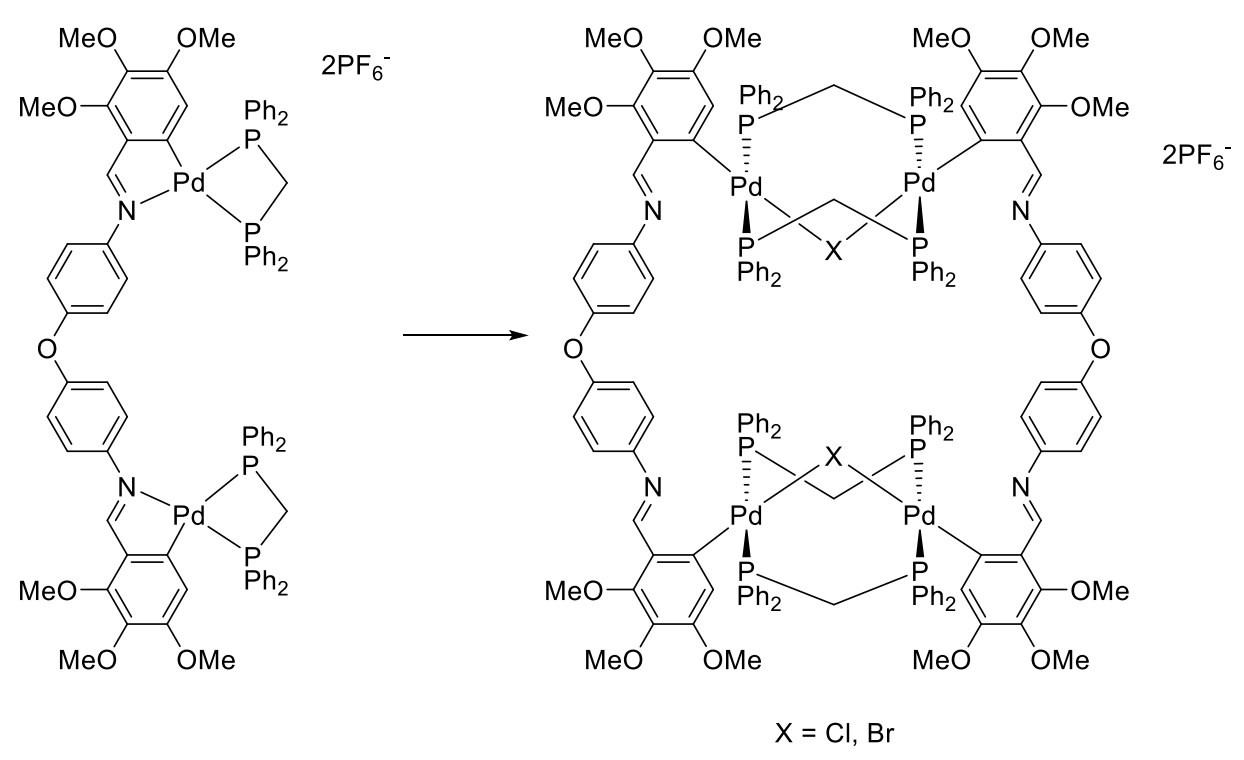

Scheme 5. Solution shift

The resulting product shifts from chelate to a bridging coordination. The core consists of two Palladium atoms, two bridging dppm units and one bridging chlorido ligand.

\section{Results}

All the compounds were characterized by CHNS elemental analysis, proton and phosphorous nuclear magnetic resonance (NMR) in solution and single-crystal X-ray diffraction for the final products.

\subsection{Elemental analysis}

Elemental analyses were performed with a Fisons elemental analyzer, Model 1108; the results obtained are shown in Table 1.

Table 1. Results of the CHNS elemental analysis

\begin{tabular}{cccc}
\hline Compound & $\begin{array}{c}\text { \% C } \\
\text { (Found/Calcd.) }\end{array}$ & $\begin{array}{c}\text { \% H } \\
\text { (Found/Calcd.) }\end{array}$ & $\begin{array}{c}\text { \% N } \\
\text { (Found/Calcd.) }\end{array}$ \\
\hline Ligand & $68.8 / 69.0$ & $5.9 / 5.8$ & $5.1 / 5.0$ \\
Cyclometallated & $48.6 / 48.8$ & $4.2 / 4.1$ & $3.3 / 3.2$ \\
Chlorido bridge & $46.2 / 45.9$ & $3.2 / 3.3$ & $3.1 / 3.0$ \\
Bromido bridge & $41.2 / 41.5$ & $3.2 / 3.3$ & $3.1 / 3.0$ \\
\hline
\end{tabular}

The results are consistent with the proposed structures. 


\subsection{Nuclear magnetic resonance}

The NMR is a very useful technique for organic and inorganic chemistry. For this analysis it was used a Varian Inova $400 \mathrm{MHz}$ spectrometer.

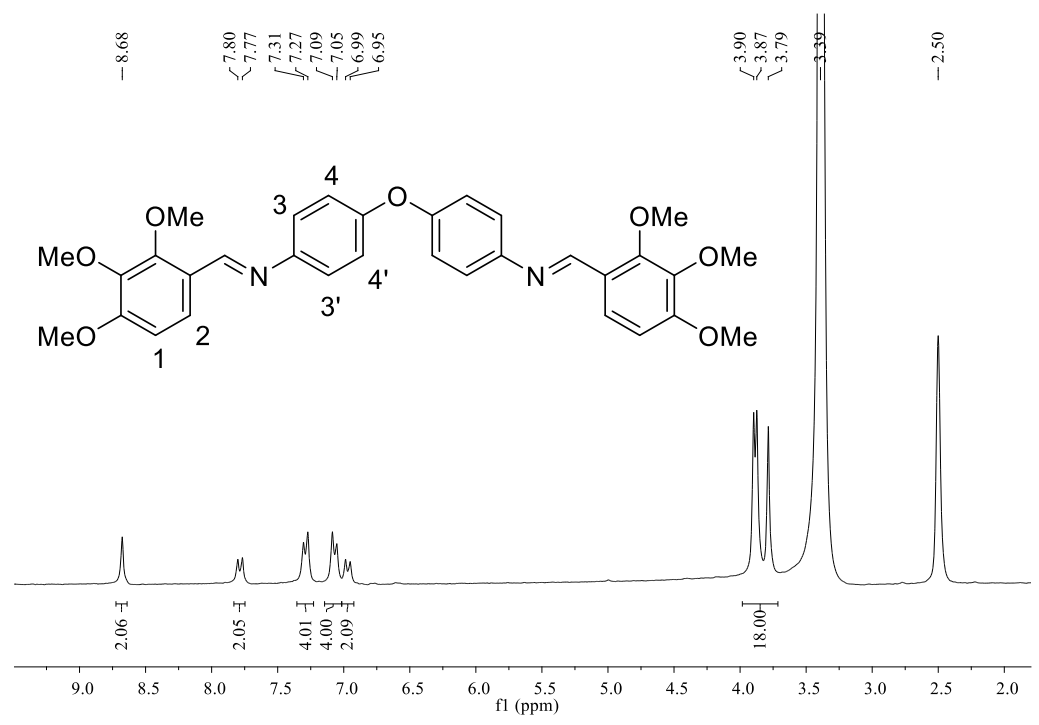

Figure 1. ${ }^{1} \mathrm{H}-\mathrm{NMR}$ from the ligand in dmso-d 6

${ }^{1} \mathrm{H}$ NMR (DMSO-d6, $\left.\mathrm{\delta} / \mathrm{ppm}, \mathrm{J} / \mathrm{Hz}\right): 8.68(\mathrm{~s}, 2 \mathrm{H}, \mathrm{HC}=\mathrm{N}) ; 7.78\left(\mathrm{~d}, 2 \mathrm{H}, \mathrm{H} 2,{ }^{3} \mathrm{JH} 2 \mathrm{H} 1=8.7\right) ; 7.28(\mathrm{~d}, 4 \mathrm{H}, \mathrm{H} 3 \mathrm{H} 3$ ', $\mathrm{N}=8.3)$; 7.07 (d, 4H, H4H4', N = 8.3); 6.97 (d, 2H, H1, 3JH1H2 = 8.7); 3.90 (s, 6H, MeO); 3.87 (s, 6H, MeO); 3.79 (s, 6H, MeO).

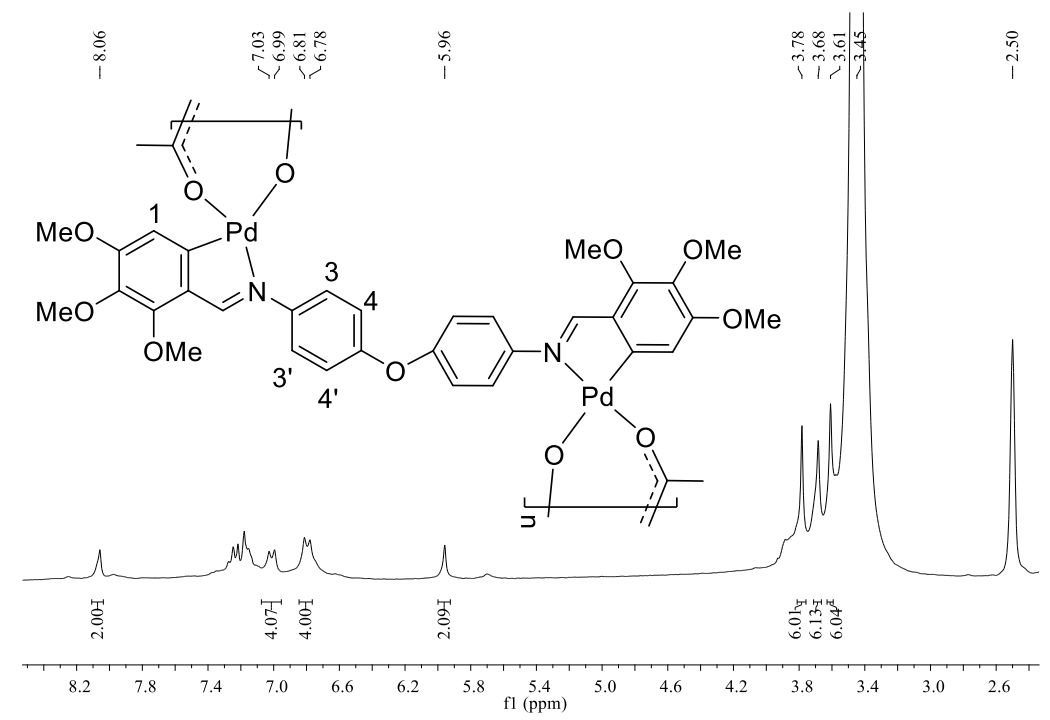

Figure 2. ${ }^{1} \mathrm{H}-\mathrm{NMR}$ from the cyclometallated compound in $\mathrm{dmso}-\mathrm{d} 6$

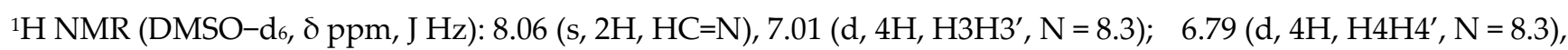
5.96 (s, 2H, H1), 3.78 (s, 6H, MeO), 3.68 (s, 6H, MeO), 3.61 (s, 6H, MeO), 2.17 (s, 3H, MeCO2), 1.48 (s, 3H, MeCO2). 


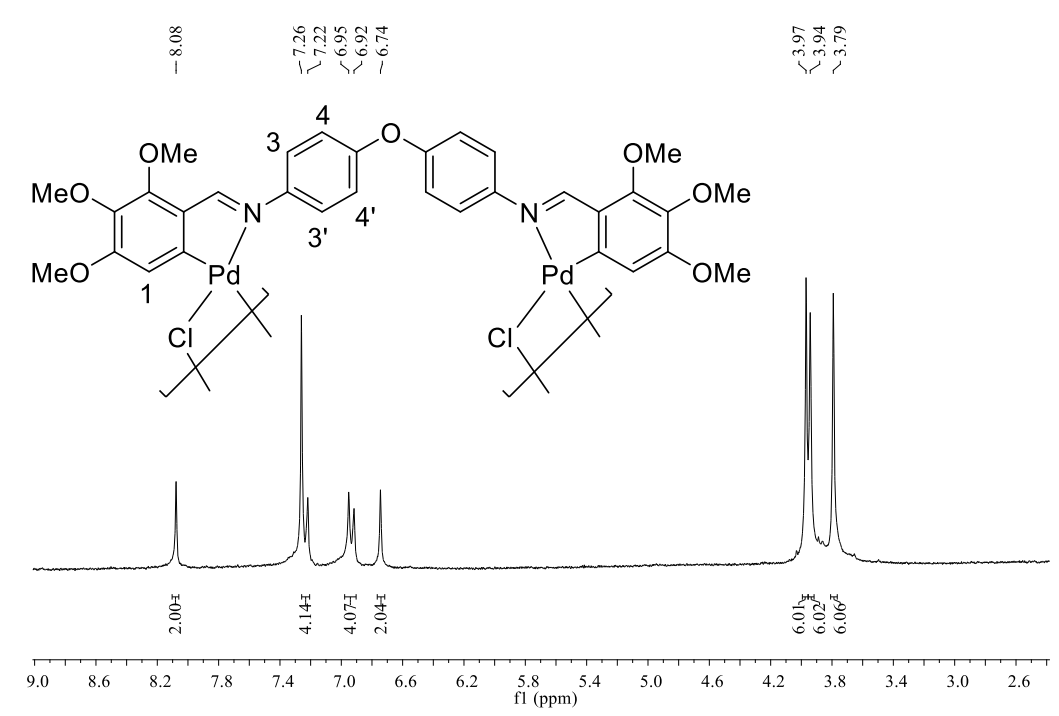

Figure 3. ${ }^{1} \mathrm{H}-\mathrm{NMR}$ from the chlorido bridging compound in $\mathrm{cdcl}_{3}$

${ }^{1} \mathrm{H}-\mathrm{NMR}\left(\mathrm{CDCl}_{3}, \delta \mathrm{ppm}, \mathrm{J} \mathrm{Hz}\right): 8.08$ (s, 2H, HC=N), $7.23\left(\mathrm{~d}, 4 \mathrm{H}, \mathrm{H} 3 \mathrm{H} 3{ }^{\prime}, \mathrm{N}=8.7\right), 6.93\left(\mathrm{~d}, 4 \mathrm{H}, \mathrm{H} 4 \mathrm{H} 4{ }^{\prime}, \mathrm{N}=8.7\right), 6.74$ (s, 2H, H1), 3.97 (s, 6H, MeO), 3.94 (s, 6H, MeO), 3.79 (s, 6H, MeO).

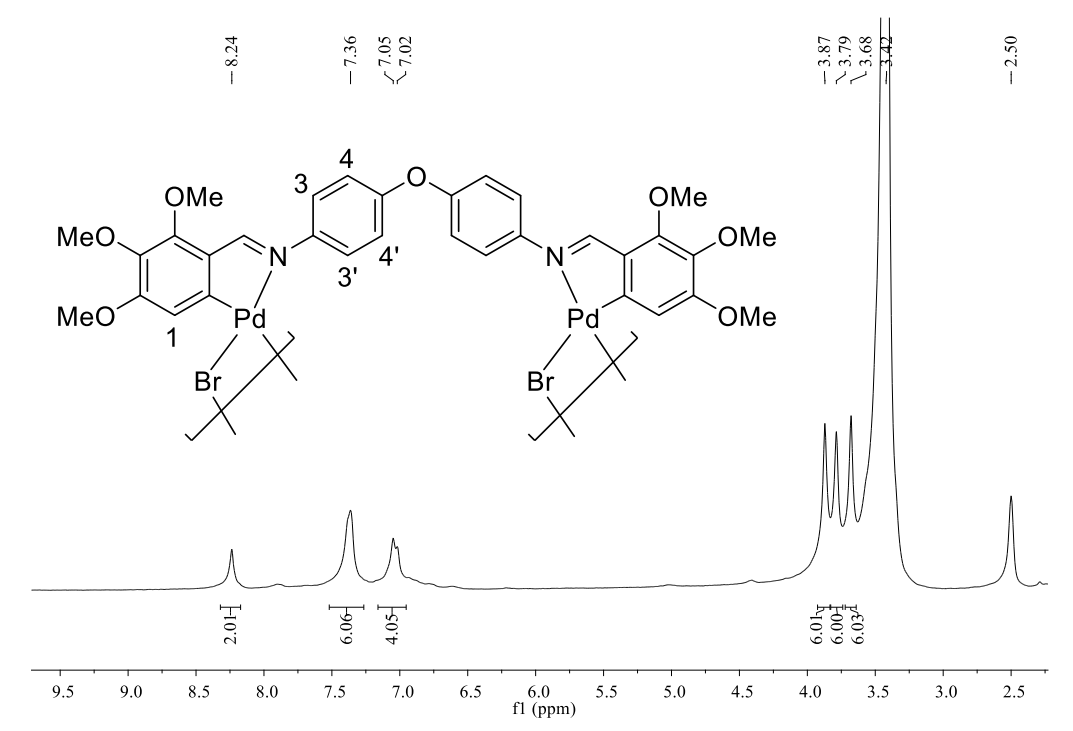

Figure 4. ${ }^{1} \mathrm{H}-\mathrm{NMR}$ from the bromido bridging compound in dmso-d 6

${ }^{1} \mathrm{H}-\mathrm{NMR}\left(\mathrm{DMSO}-\mathrm{d}_{6}, \delta \mathrm{ppm}, \mathrm{J} \mathrm{Hz}\right): 8.24(\mathrm{~s}, 2 \mathrm{H}, \mathrm{HC}=\mathrm{N}), 7.36\left(\mathrm{~m}, 4 \mathrm{H}, \mathrm{H} 3 \mathrm{H} 3{ }^{\prime}\right), 7.36$ (m, 2H, H1), $6.99(\mathrm{~m}, 4 \mathrm{H}$, $\left.\mathrm{H} 4 \mathrm{H} 44^{\prime}\right), 3.83$ (s, 6H, MeO), 3.75 (s, 6H, MeO), 3.64 (s, 6H, MeO). 


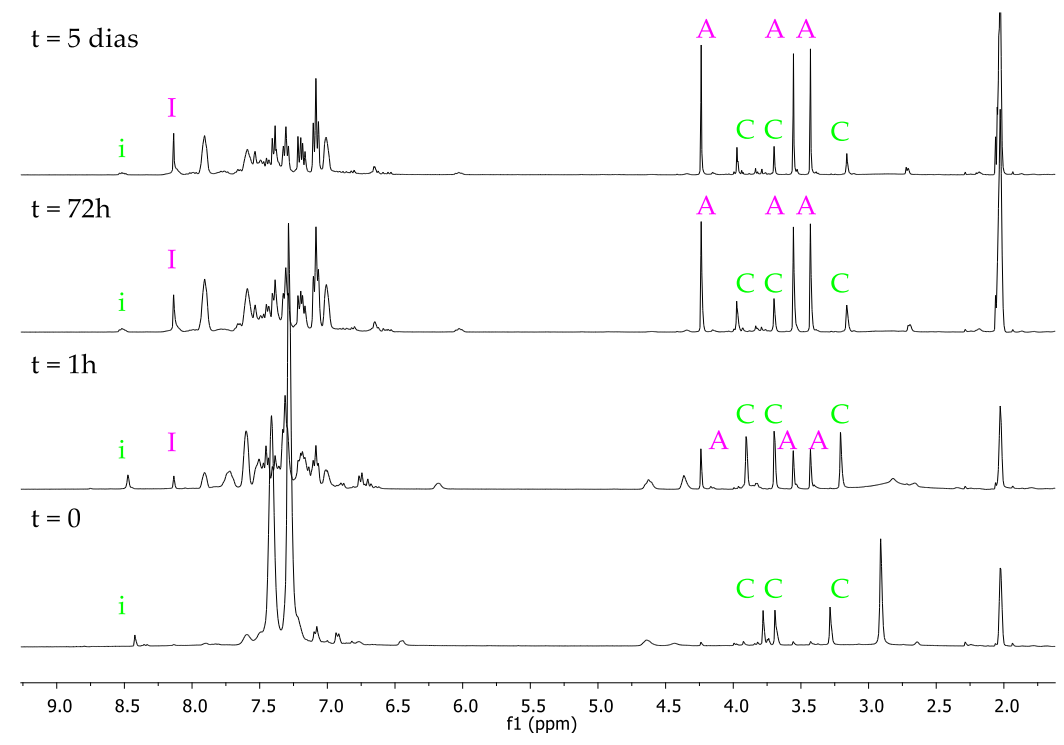

Figure 5. Shift of the phosphane palladacycle observed by ${ }^{1} \mathrm{H}-\mathrm{NMR}$ in acetone-d6
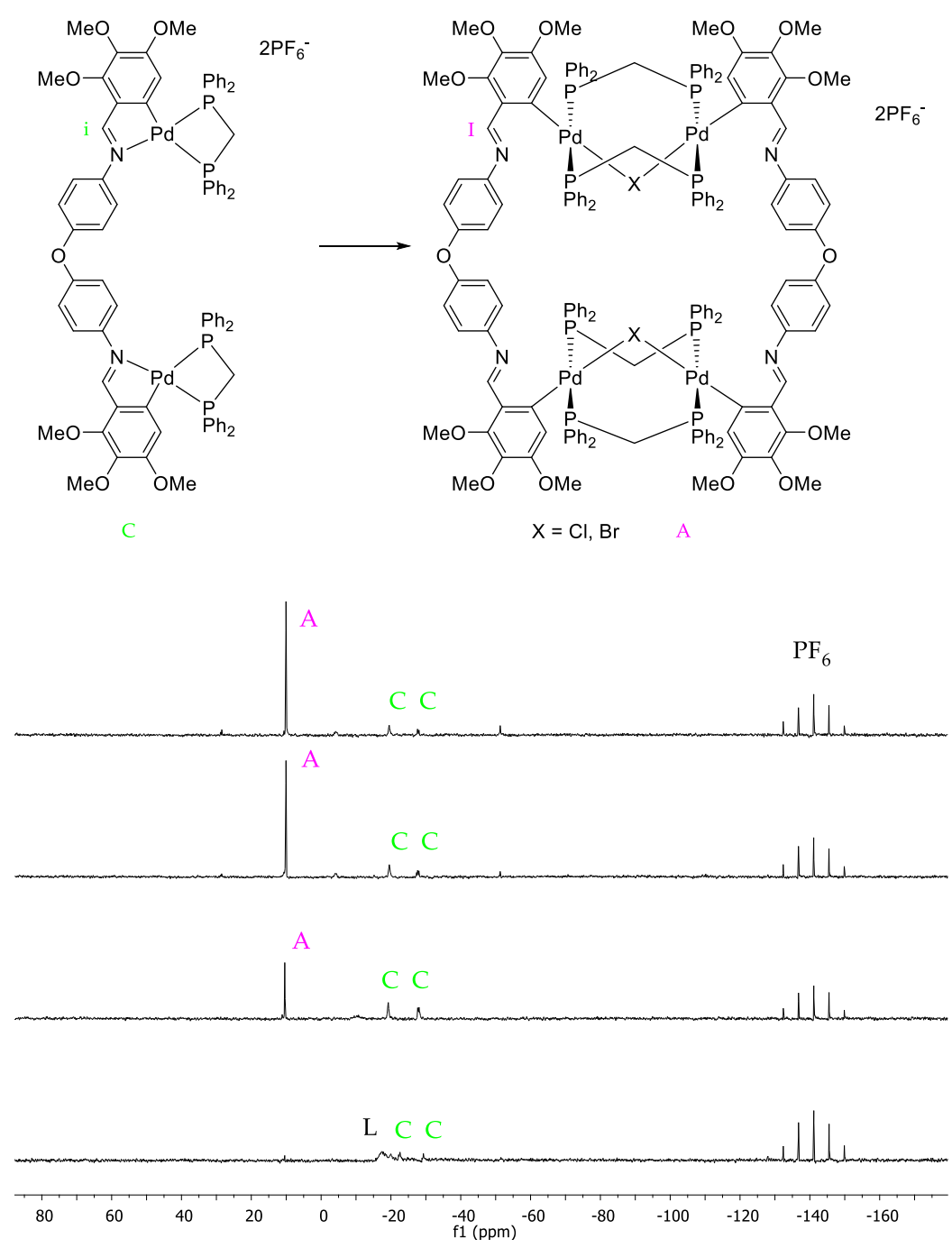

Figure 6. Shift of the phosphane palladacycle observed by ${ }^{31} \mathrm{P}-\left\{{ }^{1} \mathrm{H}\right\}-\mathrm{NMR}$ in acetone- $\mathrm{d} 6$. $\mathrm{L}=d p p m$

The time-dependent shift can be easely followed by close inspection of the ${ }^{1} \mathrm{H}$ and ${ }^{31} \mathrm{P}$ NMR spectra. 


\subsection{Single-crystal X-ray}

a)

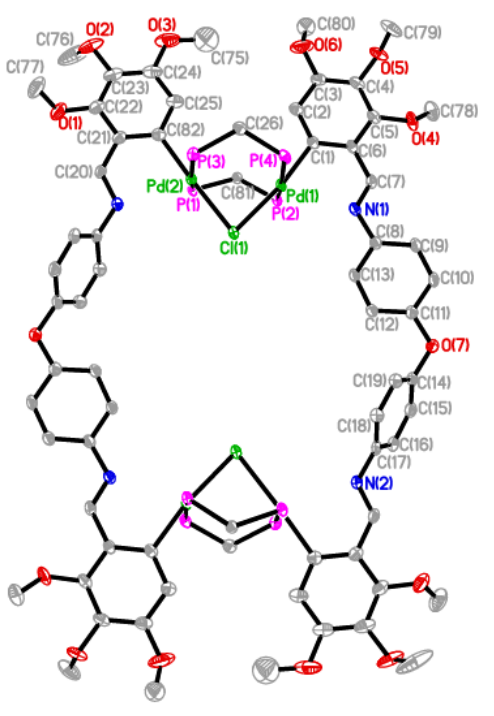

b)

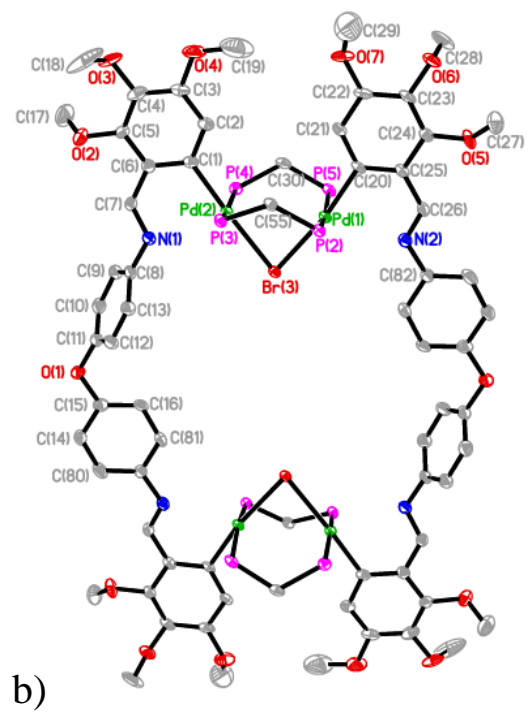

Figure 7. a) Thermal ellipsoid plot with chlorido for the asymmetric unit. Solvent molecules, hydrogen atoms and phosphane phenyls have been omitted for clarity. b) Thermal ellipsoid plot with bromido for the asymmetric unit. Solvent molecules, hydrogen atoms and phosphane phenyls have been omitted for clarity.

Table 2. Crystal data and structure refinement

\begin{tabular}{|c|c|c|}
\hline Compound & a) & b) \\
\hline Identification code & $2 b$ & $3 b$ \\
\hline Empirical formula & $\mathrm{C}_{176} \mathrm{H}_{172} \mathrm{Cl}_{2} \mathrm{~F}_{12} \mathrm{~N}_{4} \mathrm{O}_{20} \mathrm{P}_{10} \mathrm{Pd}_{4}$ & $\mathrm{C}_{85} \mathrm{H}_{80} \mathrm{Br} \mathrm{F}_{6} \mathrm{~N}_{2} \mathrm{O}_{8} \mathrm{P}_{5} \mathrm{Pd}_{2}$ \\
\hline Formula weight & 3697.37 & 1819.07 \\
\hline Temperature & $97(2) \mathrm{K}$ & $100(2) \mathrm{K}$ \\
\hline Wavelength & $0.71073 \AA$ & $0.71073 \AA$ \\
\hline Crystal system & Triclinic & Triclinic \\
\hline Space group & $\mathrm{P}-1$ & P-1 \\
\hline \multirow[t]{3}{*}{ Unit cell dimensions } & $\mathrm{a}=16.4987(6) \AA ̊$. & $\mathrm{a}=16.4980(17) \AA ; \alpha=83.263(7)^{\circ}$. \\
\hline & $b=16.5332(6) \AA ; ; \beta=71.882(2)^{\circ}$. & $b=16.5610(16) \AA ; \beta=71.977(7)^{\circ}$. \\
\hline & $c=17.1548(5) \AA ; \gamma=75.240(2)^{\circ}$. & $c=17.1294(19) \AA ; \gamma=75.228(7)^{\circ}$ \\
\hline Volume & $4295.6(3) \AA^{3}$ & $4299.7(8) \AA^{3}$ \\
\hline Z & 1 & 2 \\
\hline Density (calculated) & $1.429 \mathrm{Mg} / \mathrm{m}^{3}$ & $1.405 \mathrm{Mg} / \mathrm{m}^{3}$ \\
\hline Absorption coefficient & $0.614 \mathrm{~mm}^{-1}$ & $1.042 \mathrm{~mm}^{-1}$ \\
\hline$F(000)$ & 1892 & 1848 \\
\hline Crystal size & $0.250 \times 0.220 \times 0.160 \mathrm{~mm}^{3}$ & $0.160 \times 0.150 \times 0.090 \mathrm{~mm}^{3}$ \\
\hline Theta range for data collection & 1.275 to $25.000^{\circ}$. & 1.273 to $25.000^{\circ}$. \\
\hline Index ranges & $-19<=\mathrm{h}<=19,-19<=\mathrm{k}<=19,-20<=1<=20$ & $-19<=\mathrm{h}<=19,-19<=\mathrm{k}<=19,-20<=1<=20$ \\
\hline
\end{tabular}




\begin{tabular}{|c|c|c|}
\hline Reflections collected & 140354 & 122609 \\
\hline Independent reflections & $15101[\mathrm{R}(\mathrm{int})=0.0442]$ & $15141[\mathrm{R}(\mathrm{int})=0.0595]$ \\
\hline Completeness to theta $=25.000^{\circ}$ & $99.8 \%$ & $99.9 \%$ \\
\hline Absorption correction & Semi-empirical from equivalents & Semi-empirical from equivalents \\
\hline Max. and min. transmission & 0.9010 and 0.8216 & 0.912 and 0.851 \\
\hline Refinement method & Full-matrix least-squares on $\mathrm{F}^{2}$ & Full-matrix least-squares on $\mathrm{F}^{2}$ \\
\hline Data / restraints / parameters & $15101 / 774$ / 1046 & 15141 / 0 / 962 \\
\hline Goodness-of-fit on $\mathrm{F}^{2}$ & 1.091 & 1.265 \\
\hline Final $R$ indices [I $>2 \operatorname{sigma}(\mathrm{I})]$ & $\mathrm{R} 1=0.0442, \mathrm{wR} 2=0.1292$ & $\mathrm{R} 1=0.0437, \mathrm{wR} 2=0.1252$ \\
\hline $\mathrm{R}$ indices (all data) & $\mathrm{R} 1=0.0515, \mathrm{wR} 2=0.1339$ & $\mathrm{R} 1=0.0547, \mathrm{wR} 2=0.1301$ \\
\hline Largest diff. peak and hole & 2.151 and -0.969 e. $\AA^{-3}$ & 2.036 and -0.918 e. $\AA^{-3}$ \\
\hline
\end{tabular}

Funding: "This research was funded by Xunta de Galica (Galicia, Spain) under the Grupo de Referencia Competitiva Programme (Project GRC2015/009) and by the Ministerio de Educación, Cultura y Deporte, F. Reigosa grant FPU15/07145 and F. Lucio-Martínez grant FPU13/05014".

Conflicts of Interest: “The authors declare no conflict of interest."

\section{References}

1. García-López, J.A.; Frutos-Pedreño, R.; Bautista, D.; Saura-Llamas, I. and Vicente, J. Norbornadiene as a Building Block for the Synthesis of Linked Benzazocinones and Benzazocinium Salts through Tetranuclear Carbopalladated Intermediates. Organometallics 2017, 36, 372-383, 10.1021/acs.organomet.6b00795.

2. Tsuji, J., Palladium Reagents and Catalysts. Innovations in Organic Synthesis. Wiley \& Sons: Chichester, [u. a.] 1995; ISBN 0-471-95483-7.

3. Doherty, S.; Knight, J.G.; Ward, N.A.B.; Bittner, D.M.; Wills, C.; McFarlane, W.; Clegg, W. and Harrington, R.W. Electron-Rich Trialkyl-Type Dihydro-KITPHOS Monophosphines: Efficient Ligands for Palladium-Catalyzed Suzuki-Miyaura Cross-Coupling. Comparison with Their Biaryl-Like KITPHOS Monophosphine Counterparts. Organometallics 2013, 32, 1773-1788, 10.1021/om3011992.

4. Chellan, P.; Nasser, S.; Vivas, L.; Chibale, K. and Smith, G.S. Cyclopalladated complexes containing tridentate thiosemicarbazone ligands of biological significance: Synthesis, structure and antimalarial activity. J. Organomet. Chem. 2010, 695, 2225-2232, 10.1016/j.jorganchem.2010.06.010.

5. Antelo, J.M.; Adrio, L.; Bermúdez, B.; Martínez, J.; Teresa Pereira, M.; Ortigueira, J.M.; López-Torres, M. and Vila, J.M. Spectroscopic and solid state characterization of bimetallic terdentate [C,N,S] thiosemicarbazone Palladium(II) metallacycles with bridging and chelating [P,P] diphosphine ligands. Journal of Organometallic Chemistry 2013, 740, 83-91, 10.1016/j.jorganchem.2013.04.036.

(C) 2018 by the authors. Submitted for possible open access publication under the terms and conditions of the Creative Commons Attribution (CC BY) license (http://creativecommons.org/licenses/by/4.0/). 